\title{
Profile and Knowledge of Community Health Agents (CHAS) of Cajamar City, Brazil
}

\section{Perfil e Conhecimento dos Agentes Comunitários de Saúde (ACS) do Município de Cajamar, Brasil}

\author{
Débora Almeida Guimaraes ${ }^{\mathrm{a}}$; Aline Veroneze de Mello ; Hellen Daniela de Sousa Coelho*b \\ ${ }^{a}$ University of Paulista. SP, Brazil.

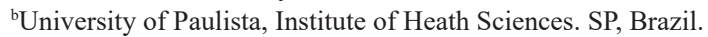 \\ *E-mail: hellencoelho@gmail.com \\ Recebido em: 30/09/2020 \\ Aprovado em: 05/01/2021
}

\begin{abstract}
Community Health Agents (CHAs) are important collaborators in combating illnesses related to poor eating habits. The objective of this work was to verify the knowledge of the community health workers of Cajamar city about food and the main diseases related to bad eating habits. This is a cross-sectional study, conducted from August to September 2011, in Cajamar city, São Paulo by trained interviewers. 57 HCWs were interviewed who answered two questionnaires, the first to characterize them and the second to obtain data on basic knowledge about food and the main diseases related to poor eating habits. $96.5 \%$ of the CHA were female, had an average of 34 years, $88.1 \%$ had two children, predominance of complete high school $(56.1 \% ; n=32)$. They had the function of CHAs as the main source of income, receiving up to three minimum wages and exercising it for at least six months (52.6\%). When the subject was food, $94.5 \%$ report that they are the first to address the issue. The main difficulties were that people did not follow the guidelines $(43 \%)$ and lack of knowledge (40\%). There was a good performance in the issues regarding chronic diseases $(76.6 \%$ of hits) and risk groups $(97 \%)$. In questions about food groups and food security, there was low performance (rate of hits of $55.2 \%$ and $55.3 \%$, respectively). The qualification of CSAs is fundamental for the improvement of the work performed, being important the use of educational strategies that provide continuous learning.
\end{abstract}

Keywords: Community Health Workers. Food Assistance. Family Health Strategy. Primary Health Care.

\section{Resumo}

Os Agentes Comunitários de Saúde (ACS) são importantes colaboradores no combate de doenças relacionadas aos maus hábitos alimentares. O objetivo deste trabalho foi verificar o conhecimento dos ACS do município de Cajamar sobre alimentação e as principais doenças relacionadas aos maus hábitos alimentares. Trata-se de um estudo transversal, realizado no periodo de agosto a setembro de 2011, no município de Cajamar, São Paulo por entrevistadores treinados. Foram entrevistados 57 ACS que responderam a dois questionários, o primeiro com intuito de caracterizá-los e o segundo para obter dados quanto aos conhecimentos básicos sobre alimentação e as principais doenças relacionadas aos maus hábitos alimentares. 96,5\% dos ACS eram do sexo feminino, possuíam em média 34 anos, 88,1\% possuíam dois filhos, predominância de ensino médio completo $(56,1 \% ; n=32)$. Possuíam a função de ACS como principal fonte de renda, recebendo até três salários mínimos e exercendo-a há pelo menos seis meses (52,6\%). Quando o assunto foi alimentação, 94,5\% relatam que são os primeiros a abordar o assunto. As principais dificuldades encontradas foram que as pessoas não seguem as orientações (43\%) e a falta de conhecimentos (40\%). Verificou-se bom desempenho nas questões que se referiam às doenças crônicas (76,6\% de acertos) e grupos de risco (97\%). Já nas questões sobre grupos alimentares e segurança alimentar, houve baixo desempenho (índice de acertos de 55,2\% e 55,3\%, respectivamente). A capacitação dos ACS mostra-se fundamental para o aprimoramento do trabalho desempenhado, sendo importante o uso de estratégias educativas que proporcionem aprendizado contínuo.

Palavras-chave: Agente Comunitário de Saúde. Assistência Alimentar. Estratégia Saúde da Família. Atencão Primária à Saúde.

\section{Introduction}

In 1991, the Ministry of Health (MS) created the National Program of Community Health Agents (PNACS) in Brazil, becoming the Program of Community Health Agents (PACS) in $1992^{1}$. The program aimed to extend coverage for basic health care through actions aimed at reducing infant and maternal mortality, weight control and providing guidance to specific groups of diseases ${ }^{1}$.

The first Brazilian state to implement the program was Ceará; its aim was to improve the capacity of the population to take care of their own health ${ }^{2}$. Soon after, PACS was introduced throughout the Northeast region, followed by the North and Central-West regions, due to the high rates of poverty and misery of these regions that generated numerous diseases ${ }^{3}$.

The Community Health Agent (CHA) is a worker who operates in two important MS programs in Brazil, the Family Health Program (PSF) and the PACS, being a key contributor to the PSF, responsible for helping to prevent diseases and promote health, and thus it becomes a link between multidisciplinary team professionals and the population ${ }^{4,5}$.

According to MS, there are five competencies assigned to the work of the CHA: Integration of the health team with the population, planning and evaluation, health promotion, 
environmental and health risk monitoring, prevention and monitoring of specific groups and morbidities, considering that in order to carry out these activities, certain health skills and knowledge are required by the agent, as established in Law No. 11.350 of October $5^{\text {th }}, 2006$, which characterizes the CHA duties ${ }^{5,6}$.

It should be emphasized that with increasing and worrying increases in the prevalence of food-related diseases and lifestyle, preventive actions are indispensable. In this context, CHA are important multipliers of actions aimed at improving health ${ }^{5}$. According to data from the World Health Organization (WHO) in 2016, chronic non-communicable diseases (NCDs) accounted for $71 \%$ of the world's deaths, which corresponded to 57 million ${ }^{7}$. Whereas in Brazil, in 2018, NCDs accounted for $74 \%$ of known causes of death ${ }^{8}$.

In this regard, CHAs training should empower them about the health-disease process, so that they can make healthier dietary choices 9 . Therefore, the nutritionist is challenged to promote effective nutritional education, with actions that promote changes in the eating habits of agents and their families ${ }^{9}$.

Therefore, the present study is justified under the importance of CHAs as multipliers of knowledge in the area of nutrition, and it is relevant to verify the level of knowledge of these agents, in order to identify possible failures and points to be improved in the training applied to these professionals. In view of the importance of CHAs in the community in health promotion and disease prevention actions, and verifying the relevance of their role as an educator in health, the objective of this study is to verify the knowledge of the community health agents (CHA) of the municipality of Cajamar, SP, Brazil.

\section{Material and Methods}

This is a cross-sectional study, carried out between August and September 2011, after the approval of the Ethics in Human Research Committee of Universidade Paulista (UNIP), in which interviews were conducted with CHAs from the municipality of Cajamar, São Paulo (SP), Brazil.

The municipality of Cajamar has three basic health units (UBS): UBS Parque São Roberto, Unidade Mista de Jordanésia and UBS Polvilho. It also has six PSF units: PSF Cajamar Centro, PSF Ponunduva, PSF Parque Maria Luiza, PSF Belo Planalto, PSF Parque Maria Aparecida and PSF do Polvilho, in which 62 Community Health Agents were present who were the subjects of this research.

Two questionnaires were used to collect data, the first, aiming to characterize CHAs and the second, whose objective was to obtain data on the basic knowledge of the agents on food and the main diseases related to bad eating habits, adapted from Pinto $(2010)^{10}$. It was verified the need to add two questions related to the difficulties encountered by the CHAs in talking about nutrition, elaborated by Pasquim ${ }^{11}$ in their study on nutrition in the Family Health Program, in addition to multiple choice questions based on the document: Food and nutrition for families of bolsa familia program: manual for community agents ${ }^{12}$, of MS. As an answer option, there was a correct alternative and two incorrect. Each question answered correctly corresponded to a point, incorrect answers were not scored. For the classification of nutritional knowledge, 4 hits were considered low for a lower/equal score, average for a knowledge level greater than 4 and equal to 9 hits and good for knowledge in nutrition greater than 9 hits. The score can range from zero to twelve points. The questions were grouped according to the subject to which they addressed, presenting four specific subjects such as chronic diseases, food groups, risk groups and food safety.

The following variables were studied for ACS characterization: age, gender, time of occupation, marital status, number of children, monthly income and level of education. The monthly income classification was distributed by bands according to the minimum wage in March/2010 of $\mathrm{R} \$ 545.00$.

The questionnaires were administered by a nutritionist and three students who graduated from the nutrition course, who were properly trained for this activity, thus avoiding inappropriate or non-uniform methods of applying the questionnaires that may cause biases.

These questionnaires passed through a pre-test (pilot), being applied to the public servants of Cajamar city hall who had the same degree of instruction as agents and who were willing to answer the questionnaires, in order to identify possible problems or doubts that could arise during the application of the questionnaire with the CHAs, thus excluding ambiguous and difficult to understand questions.

Data analysis was carried out with the help of the EPIinfo ${ }^{\mathrm{TM}}$ program, version 3.5.2, which is an integrated system of programs for microcomputers aimed at the management of epidemiological data, created by researchers from the Center of disease Control organization in the United States.

The data were collected only after the approval of the Research Ethics Committee (CEP), under protocol number 301/11 approved according to the opinion. Each participant was supplied with the Free and informed consent form - TCLE which was read by everyone and signed after all the doubts regarding the research were clarified. Each of the interviewees was given a copy of the term for contact with the researchers, if they so wished, for the doubts clarification or withdrawal of the familiar study participation that can occur at any time of the research, respecting the research ethical requirements in human beings, recommended by the National Health Council (CNS), in accordance with resolution 466/2012.

\section{Results and Discussion}

The study was carried out in the city of Cajamar, São Paulo, with 62 professionals (CHA), of which 57 participated in the research, since 5 were not present at the time of data 
collection. The mean age among the CHAs was 34 years, with standard deviation (SD) of 9.5 years and median of 33 years, with a maximum age of 55 years and a minimum age of 18 years, thus obtaining a very heterogeneous group as to age, with an expressive percentage of young adults (18 to 24 years) in this population (84\%). There was a predominance of females with $96.5 \%$ of the individuals (Table 1 ).

Table 1 - Distribution in number, percentage and accumulated percentage of the socioeconomic and demographic characteristics of CHAs. Cajamar, SP, Brazil, 2011

\begin{tabular}{|c|c|c|c|}
\hline & $\mathbf{n}$ & $\%$ & $\begin{array}{c}\% \\
\text { accumulated }\end{array}$ \\
\hline \multicolumn{4}{|l|}{ Sex } \\
\hline Male & 2 & 3.5 & 3.5 \\
\hline Female & 55 & 96.5 & 100 \\
\hline \multicolumn{4}{|l|}{ Age Range } \\
\hline $18-29$ years & 20 & 35.1 & 35.1 \\
\hline $30-41$ years & 28 & 49.1 & 84.2 \\
\hline $42-54$ years & 9 & 15.8 & 100 \\
\hline \multicolumn{4}{|l|}{ Number of children } \\
\hline 1 & 17 & 29.8 & 29.8 \\
\hline 2 & 19 & 33.3 & 63.1 \\
\hline 3 & 9 & 15.8 & 78.9 \\
\hline 4 & 3 & 5.3 & 84.2 \\
\hline 5 or more & 2 & 3.5 & 87.7 \\
\hline No children & 7 & 12.3 & 100 \\
\hline \multicolumn{4}{|l|}{\begin{tabular}{|l|} 
Marital status \\
\end{tabular}} \\
\hline Single & 17 & 29.8 & 29.8 \\
\hline Married & 28 & 49.1 & 78.9 \\
\hline Common Law Marriage & 9 & 15.8 & 94.7 \\
\hline Divorced & 1 & 1.8 & 96.5 \\
\hline Widow/Widower & 1 & 1.8 & 98.2 \\
\hline Did not reply & 1 & 1.8 & 100 \\
\hline \multicolumn{4}{|l|}{ Monthly Income } \\
\hline $1 \mathrm{SM}$ & 24 & 42.2 & 42.2 \\
\hline $2 \mathrm{SM}$ & 19 & 33.3 & 75.5 \\
\hline 3 or more & 13 & 22.8 & 98.3 \\
\hline Did not reply & 1 & 1.7 & 100 \\
\hline \multicolumn{4}{|l|}{ Schooling } \\
\hline $\begin{array}{l}\text { Incomplete elementary } \\
\text { education } \\
\end{array}$ & 1 & 1.7 & 1.8 \\
\hline Complete elementary education & 7 & 12.2 & 14 \\
\hline Incomplete high school & 10 & 17.5 & 31.6 \\
\hline Complete high school & 32 & 56.1 & 87.7 \\
\hline Technical Education & 5 & 9 & 96.5 \\
\hline Higher education & 2 & 3.5 & 100 \\
\hline
\end{tabular}

*SM: Minimum wages.

Source: Research data

Of the interviewees, $48 \%$ were married (as), and 30\% were single (as), demonstrating that most CHAs (64\%) live with a partner. Regarding the number of children, $88.1 \%$ of the CHAs had children, and the mean was 2 children per agent (Table 1).

In the socioeconomic aspect, it was observed that only one of the interviewees did not answer questions about their monthly income. It was verified that $96.5 \%$ did not have another job, with the function of CHA being his or her only source of income. There is a predominance in the studied population that has complete high school education $(56.1 \%$ $\mathrm{n}=32)$ and $12 \%(\mathrm{n}=7)$ have some degree of technical or higher education (Table 1 and Figure 1).

Figure 1 - Distribution in number and percentage distribution of CHA according to technical training area. Cajamar, SP, Brazil, 2011

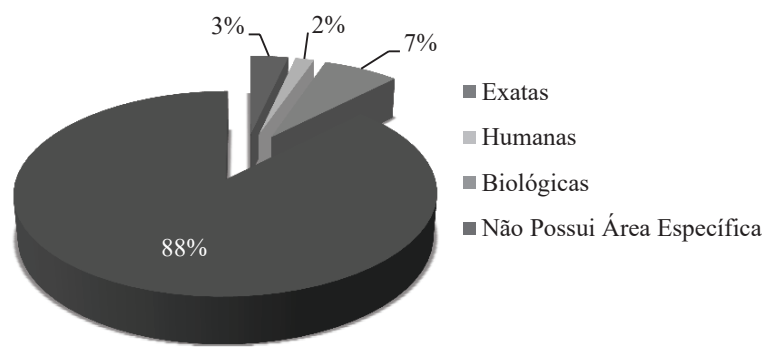

Source: Research data.

CHAs were divided into 6 teams according to the neighborhood in which the PSF headquarters is located (Table 2). The largest CHA nuclei of the municipality were located in the headquarters of Belo Planalto neighborhoods with 26.3\% and of Parque Maria Aparecida with 24.6\%. The other neighborhoods had a similar average number of agents. There was a higher prevalence of $52.6 \%$ of CHAs that had six months to one year of professional practice, and only $21.1 \%$ reported having more than two years of profession.

Table 2 - Distribution in number, percentage and accumulated percentage of the CHAs work characteristics. Cajamar, SP, Brazil, 2011

\begin{tabular}{|c|c|c|c|}
\hline & $\mathbf{n}$ & $\%$ & $\begin{array}{c}\% \\
\text { accumulated }\end{array}$ \\
\hline \multicolumn{4}{|c|}{ CHAs Headquarters (neighborhood) } \\
\hline Polvilho & 7 & 12.3 & 12.3 \\
\hline Ponunduva & 6 & 10.5 & 22.8 \\
\hline Parque Maria Luiza & 7 & 12.3 & 35.1 \\
\hline Cajamar Centro & 8 & 14 & 49.1 \\
\hline Parque Maria Aparecida & 14 & 24.6 & 73.7 \\
\hline Belo planalto & 15 & 26.3 & 100 \\
\hline \multicolumn{4}{|l|}{ Function time as CHA (months) } \\
\hline 1 to 6 & 30 & 52.6 & 52.6 \\
\hline 7 to 12 & 5 & 8.8 & 61.4 \\
\hline 13 to 24 & 9 & 15.8 & 77.2 \\
\hline Above 24 & 12 & 21.1 & 98.3 \\
\hline Did not reply & 1 & 1.7 & 100 \\
\hline \multicolumn{4}{|l|}{ Have another job } \\
\hline Yes & 2 & 3.5 & 3.5 \\
\hline No & 55 & 96.5 & 100 \\
\hline \multicolumn{4}{|l|}{ Difficulties in addressing nutrition } \\
\hline Little time in appointments & 4 & 5 & 5 \\
\hline $\begin{array}{l}\text { Lack of confidence in him/ } \\
\text { herself }\end{array}$ & 3 & 3.7 & 8.7 \\
\hline $\begin{array}{l}\text { Demotivation because people } \\
\text { do not follow the guidelines }\end{array}$ & 35 & 43.8 & 52.5 \\
\hline $\begin{array}{l}\text { Insufficient knowledge in the } \\
\text { area }\end{array}$ & 32 & 40 & 92.5 \\
\hline Others & 6 & 7.5 & 100 \\
\hline \multicolumn{4}{|c|}{ Who starts talking on the subject of nutrition first? } \\
\hline CHA & 52 & 94.5 & 94.5 \\
\hline Patient & 3 & 5.5 & 100 \\
\hline
\end{tabular}


When asked about feeding, $94.5 \%$ of the CHAs reported that they are responsible for starting the conversation and the minority $(5.5 \%)$ reported that the patient is the first to start talking about the subject (Table 2).

When asked about the main difficulties faced in talking about feeding, it was allowed to mark more than one answer option, due to the fact that some of them face several obstacles and only one option might not cover all these points (Table 2). As reported by CHAs, the main difficulties encountered were the people who did not follow the previous guidelines (43.8\%; $\mathrm{n}=35$ ), which generates a lack of motivation to accomplish this task, and then the lack of knowledge $(40 \%$; $=32)$, as the most mentioned difficulties by the CHAs.

In Figure 2, the rates of correct and error of the questions on nutrition and nutrition are presented according to specific themes. CHA presented good performance in the evaluation of the knowledge in nutrition and feeding, and $70 \%(n=40)$ answered more than four questions and 30\% $(n=17)$ had an accuracy index higher than nine questions, with no $\mathrm{CHA}$ having hit fewer than five questions. As for questions seven and twelve, which deal with the theme of breastfeeding and practices during pregnancy, they obtained the highest rates with $98.2 \%(n=56)$ and $100 \%(n=57)$ of correct answers, respectively, showing the good knowledge of CHA regarding this subject.

Knowing that knowledge about food groups is the basis for preparing any type of food orientation, there was a failure in the CHA training that obtained very low performance in the questions related to this subject, with a rate of hits of $55.2 \%$ $(\mathrm{n}=57)$. CHAs also presented low performance in food safety issues with a $55.3 \%$ rate of hits. The results of the questions related to chronic diseases already show a higher rate of hits, reaching $76.6 \%$ of the interviewees (Figure 2).

Figure 2 - Distribution of the rate of hits and errors about specific themes in nutrition and feeding. Cajamar, SP, Brazil, 2011

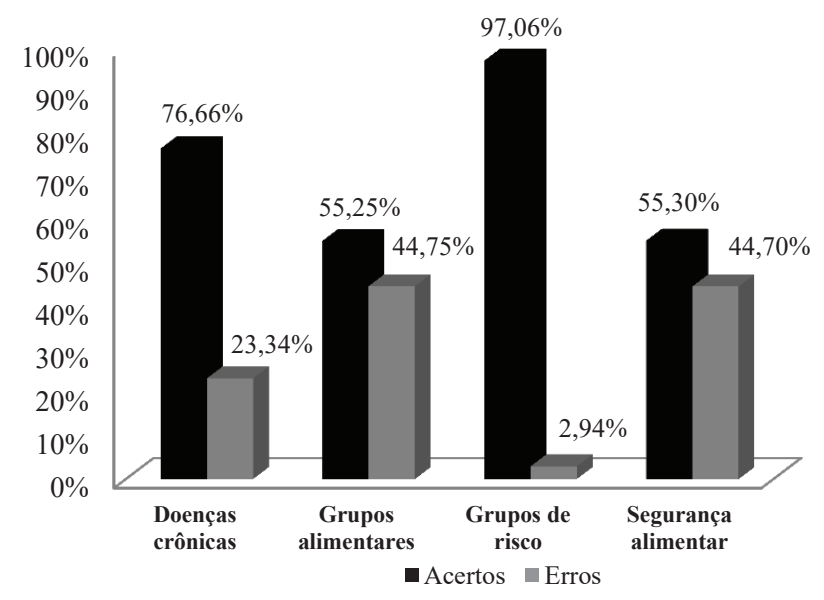

Source: Research data.

Analyzing the epidemiological data, it was verified that all CHAs are over 18, because according to MS one of the selection criteria is to be at least 18 years, thus being fully responsible civil and penally about their acts, there is no maximum age limit to practice the profession ${ }^{13}$.

The literature reports a higher prevalence of women exercising CHA function ${ }^{14}$. One of the explanations presented is the fact that the woman plays in society the role of mother and responsible for the care of the family and for the difficulty found by the male CHAs in creating bonds with families to the point that they feel at ease in order to confide them women's affairs and to have free access to residences ${ }^{14-17}$.

The CHA function presents itself as a form of entry and also as a reentry into the labor market, offering them social recognition and a way to complement the family support, since there is no need for many requirements to become a $\mathrm{CHA}^{18}$. In the present study, $88 \%$ do not have a specific technical training area and $96.5 \%$ have the function of CHA as the only source of income.

Although $88 \%$ did not have a specific training area, it was noted that the CHAs of the population evaluated had a higher level of education than necessary for the exercise of the function ( $87.7 \%$ reported having completed the high school). A similar fact to that observed in other studies, which may characterize as a factor that facilitates the work process, considering the importance of the professional in the connection between the community and the services provided ${ }^{17,19}$. According to MS, CHAs must have completed the Elementary School so that they can practice the profession ${ }^{13}$. Therefore, PACS provides employment opportunities for the neediest populations, by inserting people from the own community into this activity that requires little schooling, facilitating their entry ${ }^{18}$, which can also explain the difficulty of addressing nutrition issues, referred to by $40 \%$ of CHAs, as a lack of knowledge in the area.

Living with a partner makes individuals feel better and have more confidence ${ }^{20}$. It is observed that a large portion of CHAs live with a partner $(65 \% ; n=37)$. Equivalent results were observed in a study aimed at knowing the working conditions and evaluating the quality of life of 73 CHAs in the municipality of Londrina, Paraná (PR), verifying that $47.9 \%$ of CHAs were married and $28.7 \%$ were single ${ }^{21}$. In a study that sought the understanding the CHAs on their importance in the home visit, 15 CHAs were studied and of these $53.3 \%$ were married $^{22}$.

In a study by Musse et al. ${ }^{23}$, who sought to evaluate the CHAs competencies for epidemiological data collection, found that $82 \%$ of the agents had children and the mean was 2 children per agent, data that corroborate this study ${ }^{23}$. According to data from the Family Budget Survey (POF) 2008-2009, the average number of children per couple in Brazil is 1.9, data compatible with the ones in this study.

MS determines that CHAs should have a remuneration of at least one minimum wage per month, and it is the responsibility of the federal, municipal and state government to release resources for making payments ${ }^{13}$. Cozer ${ }^{24}$ in her research to identify the profile of the Community Health Agent of Colatina in Espírito Santo (ES), when studying 
188 CHAs, observed that $53.7 \%(n=101)$ present income between 2 to 3 minimum wages, and $19 \%(n=36)$ had more than 3 three minimum wages, with data similar to those found in the present study $(33.3 \%$ with two minimum wages and $22.8 \%$ with three or more). However, another study aimed at mapping the demographic profile and oral health practices of the CHA in small cities in the State of Piauí, observed that $72.5 \%(n=79)$ earned up to one minimum wage, which may result in a feeling of devaluation of the work carried out by the CHA and the PSF team ${ }^{25}$.

Still, several challenges are present not only by the exercise of the function, but also by the various attributions granted to them as a lack of security and knowledge, in addition to the lower socioeconomic level of the assisted populations ${ }^{26,27}$. This may explain the fact that $43.8 \%$ reported that people do not follow the guidelines mainly related to food and nutrition. There is also greater resistance to the CHA guidelines by the population, since many do not understand or believe in the information conveyed by the professionals ${ }^{28}$.

Regarding knowledge issues, differently from the present study, in which the highest rates of accuracy were for health issues during pregnancy and breastfeeding (almost 100\%), it was identified in a study that many of the guided practices were mistaken in relation to breastfeeding and the introduction of foods by CHAs, which presented insufficient knowledge on the subject ${ }^{2}$. This is a worrying fact, since CHAs are of great importance in the prenatal care of pregnant women for performing a follow-up that can guarantee their adherence to the program, in addition to avoiding complications during pregnancy ${ }^{29}$.

In a study aimed at training 14 CHAs in nutrition and feeding, a pre-test, training and test were performed in relation to their knowledge $\mathrm{e}^{30}$. The research showed that before the training, the topic chronic diseases presented an average of $54.8 \%$ of correct answers, which demonstrates a low knowledge of the CHAs on this subject ${ }^{30}$. Such data were diverging from the present research, which obtained an index of $76.6 \%$ of hits answers in this theme. On the other hand, in view of the low performance in food safety issues (55.3\%), the importance of introducing and maintaining CHA training courses is emphasized, since guidance on the theme of food and nutritional security is one of his or her main functions ${ }^{26}$.

\section{Conclusion}

CHAs generally presented a good performance in the evaluation of nutritional knowledge, however it is verified that their knowledge is superficial, not presenting a deepening in the feeding bases. This lack of deepening in the knowledge of the basic feeding points creates insecurity in CHAs, which often leads to the non-realization of the guidelines to the population. The need for a reformulation of the content presented to the $\mathrm{CHA}$ in qualification, training and recycling is verified, showing that it is important to rescue basic feeding concepts and introduce concepts of how to address questions of nutritional education with families. The nutritionist is seen as a fundamental professional for the training work in nutritional education with $\mathrm{CHA}$, so that they acquire knowledge that can make them able to recognize and solve nutritional problems.

\section{References}

1. Barros DF. Avaliação da formação dos Agentes Comunitários de Saúde no Brasil. Brasília. UnB; 2006.

2. Ávila MMM. Origem e evolução do programa de Agentes Comunitários de Saúde no Ceará. Rev Bras Prom Saúde 2012;24(2):159-168.

3. Simas PRP, Pinto ICM. Trabalho em saúde: retrato dos agentes comunitários de saúde da região Nordeste do Brasil. Ciênc Saúde Coletiva 2017;22:1865-1876. doi: https://doi. org/10.1590/1413-81232017226.01532017.

4. Romagnoli RC. Breve estudo institucionalista acerca do Programa de Saúde da Família. Rev Saúde Soc 2009;18(3):525-36.

5. Brasil. Ministério da Saúde. Secretaria de Atenção à Saúde. Departamento de Atenção Básica. Brasília: MS; 2012.

6. Brasil. Lei $n^{\circ}$. 11.350. Dispõe sobre o Aproveitamento de Pessoal Amparado pelo Parágrafo Único do art. $2^{\circ}$ da Emenda Constitucional 51, de 14 de fevereiro de 2006, e dá Outras Providências. Diário Oficial da União, Brasília; 2006.

7. WHO - World Health Organization. Global health estimates 2016: deaths by cause, age, sex, by Country and by Region, 2000-2016. Geneva: WHO; 2018.

8. Brasil. Ministério da Saúde. Secretaria de Vigilância em Saúde. Departamento de Análise em Saúde e Vigilância de Doenças não Transmissíveis. Vigitel Brasil 2018: vigilância de fatores de risco e proteção para doenças crônicas por inquérito telefônico: estimativas sobre frequência e distribuição sociodemográfica de fatores de risco e proteção para doenças crônicas nas capitais dos 26 estados brasileiros e no Distrito Federal em 2018. Brasília: MS; 2019.

9. Carvalho AT, Almeida ER, Nilson EAF, Ubarana JA, Fernandez IM, Immink M. Métodos de análise em programas de segurança alimentar e nutricional: uma experiência no Brasil. Ciênc Saúde Coletiva 2013;18(2):309-21.

10. Pinto AVM. As Potencialidades do Agente Comunitário em Saúde na efetivação da promoção da saúde: uma analise de suas ações no Município de Marília. São Paulo: USP; 2010.

11. Pasquim EM. Nutrição no Programa Saúde da Família. Brasília: UnB; 2002.

12. Brasil. Ministério da Saúde. Secretaria de Atenção em Saúde. Departamento de Atenção Básica. Alimentação e Nutrição para as Famílias do Programa Bolsa Família: manual para os Agentes Comunitários de Saúde. Brasília: MS; 2010.

13. Brasil. Programa Agentes Comunitários de Saúde - PACS. Brasília: MS; 2001.

14. Castro TA, Davoglio RS, Nascimento AAJ, Santos KJS, Coelho GMP, Lima KSB. Agentes Comunitários de Saúde: perfil sociodemográfico, emprego e satisfação com o trabalho em um município do Semiárido Baiano. Cads Saúde Coletiva 2017;25(3):294-301. doi: https://doi.org/10.1590/1414$462 \times 201700030190$

15. Kluthcovsky ACGC, Takayanagui AMM, Santos CB, 
Kluthcovsky FA. Avaliação da qualidade de vida e Agentes Comunitários de Saúde: a contribuição relativa das variáveis sociodemográficas e dos domínios da qualidade de vida. Rev Psiquiatr Rio Grande do Sul 2007;29:176-83.

16. Nascimento CMB. Análise do cumprimento das práticas dos Agentes Comunitários de Saúde em Municípios da Região Metropolitana do Recife. Recife: Fundação Oswaldo Cruz; 2008.

17. Moreira IJB, Horta JA, Duro LN, Borges DT, Cristofari $\mathrm{AB}$, Chaves J, et al. Perfil sociodemográfico, ocupacional e avaliação das condições de saúde mental dos trabalhadores da Estratégia Saúde da Família em um município do Rio Grande do Sul, RS. Rev Bras Med Família Com 2016;11(38):1-12.

18. Muller PA, Sehnem L, Assunção AN. A qualificação dos agentes comunitários de saúde: uma abordagem a três municípios do vale. Rev Jovens Pesq 2013;3(1):169-178.

19. Lino MM. Perfil socioeconômico, demográfico e de trabalho dos Agentes Comunitários de Saúde. Cogitare Enferm 2012;17(1):57-64.

20. Comin FS, Santos MA. Satisfação com a vida e satisfação diádica: correlações entre construtores de bem-estar. Rev Psicol USF 2010;15(2):249-56.

21. Ursine BL, Trelha CS, Nunes EFPA. O Agente Comunitário de Saúde na Estratégia de Saúde da Família: uma investigação das condições de trabalho e da qualidade de vida. Rev Bras Saúde Ocup 2010;35(122):327-39.

22. Souza EB, Almeida TBS, Barbosa SP. Compreensão dos agentes comunitários de saúde sobre a importância do seu papel na visita domiciliar. Rev Enferm Integ 2009;2(2):32031 .

23. Musse JO, Marques RS, Lopes FRL, Monteiro KS, Santos
SC. Avaliação de competências de Agentes Comunitários de Saúde para coleta de dados epidemiológicos. Ciênc Saúde Coletiva, 2015;20(2):525-36. doi: http://dx.doi. org/10.1590/1413-81232015202.01212014.

24. Cozer TB, Miotto MHM, Pandolfi M. Perfil do Agente Comunitário de Saúde de Colatina, Espírito Santo. Rev Odontol UFES 2008;10:31-36.

25. Moura MS, Carvalho CJ, Amorim JTC, Marques MFSS, Moura LFAD, Mendes RF. Perfil e práticas de saúde bucal do Agente Comunitário de Saúde em Municípios Piauienses de pequeno porte. Rev Ciênc Saúde Coletiva 2010;15(Supl.1):1487-95.

26. Costa SM, Araújo FF, Martins LV, Nobre LLR, Araújo FM, Rodrigues CAQ. Agente Comunitário de Saúde: elemento nuclear das ações em saúde. Ciênc Saúde Coletiva 2013;18(7):2147-56.

27. Mascarenhas CHM, Prado FO, Fernandes MH. Fatores associados à qualidade de vida de agentes comunitários de saúde. Ciênc Saúde Coletiva 2013;18(5):1375-86.

28. Barros IS, Oliveira-Costa MS, Oliveira RC, Rehem TCMSB, Sousa MF, Mendonça AVM. Alimentação saudável na mídia de massa e promoção da saúde: percepções sociais de agentes comunitários. Braz J Health Res 2018;20(2):35-43.

29. Gonçalves R, Urasaki MBM, Merighi MAB, D’Avila CG. Avaliação da efetividade da assistência pré-natal de uma Unidade de Saúde da Família em um Município da Grande São Paulo. Rev Bras Enferm 2008;61(3):349-53.

30. Siqueira M, Lustosa BHB, Santos LAS, Dias LCGD. Ações educativas em nutrição em uma Unidade de Programa de Saúde da Família do Município de Botucatu, SP: relato de experiência. Rev Simbio-Logias 2009;2(1):1-8 